\title{
PENILAIAN KINERJA MANAJEMEN BANK SYARIAH GUNA MENINGKATKAN KUALITAS PELAYANAN TERHADAP NASABAH DENGAN INTEGRASI DIMENSI MODEL CARTER DAN FUZZY SERVQUAL (Studi Kasus pada BNI Syariah Kantor Cabang Surabaya)
}

\author{
Abdul Djalal \\ ${ }^{1}$ Jurusan Teknik Industri, FTI Universitas Islam Indonesia \\ Kampus UII terpadu, Jl. Kaliurang km 14,5 Sleman, Yogyakarta \\ Email : abdul.djalal@uii.ac.id
}

\begin{abstract}
Carter model is a quality service dimension developed by Parasuraman et al to measures service quality which covers Assurance, Reliability, Tangible, Empathy and Responsiveness. The research subject was a syariah company, therefore Compliance dimension is exercised. The instruments applied to measure service quality is questioner in Linkert scale and distributed to costumer. Due to the subjectivity contained in received questioner answers, Fuzzy is utilized to transform it into a quantitative value as an input for Servqual. Thus, servqual is applied to calculate the gap between customer expectations and perceptions of the service offered. By practicing Cartesian diagram, the attributes need to be addressed were attained. The largest gap is in the attribute called "Promised service time" in Reliability dimension with 0.556.
\end{abstract}

Keywords : Quality Service Dimension, Fuzzy Servqual, Gap, Atribute.

\section{PENDAHULUAN}

Saat ini sektor jasa perbankan syariah memegang peranan penting dalam perekonomian dunia. Pengaruh globalisasi mengakibatkan kebutuhan akan jasa semakin meningkat baik kualitas maupun kuantitas. Peranan sektor jasa pun semakin lama semakin luas dan canggih dalam kehidupan perekonomian. Krisis ekonomi yang berkepanjangan di Indonesia telah melumpuhkan sebagian besar dunia usaha. Salah satu sektor yang menerima dampak terberat adalah sektor perbankan. Persaingan di industri perbankan akhir - akhir ini semakin ketat, tidak hanya di kota - kota besar, melainkan sudah mencapai ke daerahdaerah dengan jaringan yang cukup luas. Kondisi semacam ini merupakan sebuah tantangan berat bagi perbankan syariah. Sektor perbankan syariah memegang peranan penting dalam perekonomian negara, karena pada perbankan syariah tidak mengenal rezim bunga, namun menawarkan kerjasama saling menguntungkan antara pemilik modal (shahibul mal) dengan pengusaha (mudharib) melalui skema mudharabah atau musyarakah. Karakteristik sistem perbankan syariah yang beroperasi berdasarkan prinsip bagi hasil memberikan alternatif sistem perbankan yang saling menguntungkan bagi masyarakat dan bank, serta menonjolkan aspek keadilan dalam bertransaksi, investasi yang beretika, mengedepankan nilai - nilai kebersamaan dan persaudaraan dalam berproduksi, dan menghindari kegiatan spekulatif dalam bertransaksi keuangan (Nikensari, 2012).

Dunia perbankan semakin dibutuhkan oleh seluruh lapisan masyarakat baik di negara maju maupun berkembang. Dengan adanya kondisi tersebut maka perbankan syariah dewasa ini dituntut untuk semakin mengoptimalkan pelayanan kepada nasabah agar kepuasaan nasabah tetap terjaga. Keadaan ini tidak hanya terjadi pada perbankan pemerintah tetapi juga bank swasta. Dilihat secara fisik kondisi dan fungsi masing - masing bank adalah sama. Hal yang dapat membedakan antara bank yang satu dengan yang lainnya adalah tingkat pelayanan kepada masyarakat pengguna jasa bank. Dalam persaingan antar bank yang semakin ketat, faktor kepuasan 
nasabah menjadi perhatian serius, mereka mempunyai pengungkapan yang beraneka ragam untuk memberi sesuatu seperti apa yang diharapkan.

Persepsi terhadap kualitas pelayanan akan menjadi faktor penting bagi seorang konsumen dalam memutuskan bank sebagai tempat terpercaya untuk menabung dan melakukan transaksi perbankan lainnya. Sejalan dengan meningkatnya persaingan, hanya perusahaan yang memperhatikan kepuasan pelangganlah yang mampu bertahan dan berkembang (Rahmayanty, 2010). Kualitas pelayanan sebuah bank adalah indikator subyektif yang sangat berpengaruh terhadap perkembangannya. Umumnya masalah pelayanan sebuah bank terkait dengan kualitas sumber daya manusia (tingkat kinerja) pada bank tersebut. Jasa akan menjadi sesuatu bermanfaat apabila didasarkan pada kepentingan pelanggan dan kinerja perusahaan. Artinya perusahaan harus mencurahkan perhatiannya pada halhal yang memang dianggap penting oleh para pelanggan atau nasabahnya

Dengan berbagai produk dan kapabilitas layanan yang bervariasi, perbankan syariah menjadi alternatif sistem perbankan yang kredibel dan dapat dinikmati oleh seluruh golongan masyarakat, sehingga tak heran jika banyak orang memilih menggunakan jasa mereka. Berdasarkan uraian diatas, maka penulis tertarik untuk melakukan penelitian tentang Kepuasan Nasabah Terhadap Kualitas Pelayanan pada Perbankan Syariah, adalah dengan mengukur kualitas pelayanan tersebut dengan mengetahui kesenjangan yang terjadi antara persepsi / kepuasan nasabah dan harapan / kepentingan nasabah dengan melakukan pengukuran menggunakan skala Likert dengan melakukan proses Fuzzyfikasi terlebih dahulu pada beberapa nasabah / konsumen dan kemudian menempatkannya dalam dimensi pelayanan: Reliability, Responsiveness, Assurance, Empathy, Tangible dan Compliant, sehingga dapat menentukan atribut - atribut yang perlu dikembangkan dengan menggunakan sistem ranking. Tujuan penggunaaan Fuzzy -
Servqual dan pengukuran kinerja dalam pengukuran kesenjangan adalah untuk melakukan program perbaikan dalam pengendalian jasa layanan yang digunakan sebagai alternatif usulan dalam perbaikan kualitas jasa yang berorientasi terhadap kepuasan pelanggan, sebagai salah satu strategi perusahaan dalam memberdayakan Total Quality Service (Tjiptono, 2005).

Permasalahan pertama yang dijawab dalam penelitian ini adalah apakah kualitas pelayanan yang selama ini diberikan oleh perusahaan sesuai dengan harapan nasabahnya. Kedua adalah mencari atribut atribut apa sajakah yang harus diperhatikan dalam upaya meningkatkan kualitas pelayanan perusahaan.

\section{METODE PENELITIAN}

Artikel ini membahas keterlibatan fuzzy yang digunakan untuk mempresisikan pengaruh nilai subyektif dari responden, sebagai input dalam perhitungan servqual, dimana dalam perhitungan servqual tersebut terdapat integrasi dari dimensi model Carter (Astuti, 2009). Hal yang pertama dilakukan adalah menentukan ukuran responden, kemudian menyusun kuesioner, lalu mendistribusikannya (Bhuono, 2005). Setelah didapatkan feedback dari kuesioner yang didistribusikan, maka data di olah untuk menjaga reliabilitas data. Langkah selanjutnya adalah menentukan fuzzy set dilanjutkan perhitungan servqual. Hasil dari perhitungan akan digunakan untuk identifikasi atribut analisis solusi yang memungkinkan (Kusumadewi, 2003).

\section{HASIL DAN PEMBAHASAN}

Untuk ukuran sampel menggunakan rumus Error dengan tingkat kepercayaan sebesar $90 \%$, derajat ketelitian $\alpha=10 \%=$ 0,1 , maka didapatkan ukuran minimal responden yang digunakan adalah sebanyak 68 responden (Sugiyono, 2007). Dalam penelitian ini digunakan 100 responden, sehingga sudah mencukupi ukuran minimal responden sebanyak 68 responden. 
Pengujian validitas dilakukan dengan menggunakan software SPSS 16 yang hasilnya dapat dilihat pada kolom Corrected Item-Total Correlation. Uji validitas pada penelitian ini dilakukan 2 iterasi karena pada iterasi pertama terdapat 2 atribut yang tidak valid, sehingga 2 atribut tersebut dibuang dan dilakukan uji validitas lagi untuk memastikan apakah masih terdapat atribut yang tidak valid. Dari 36 atribut pertanyaan, 2 atribut tidak valid, sehingga menyisakan 34 atribut pertanyaan. Hal ini berarti atribut atribut tersebut telah mampu mengungkapkan sesuatu yang menjadi sasaran pokok pengukuran yang dilakukan dengan atribut tersebut (Sujarweni, 2014).

Pengujian reliabilitas dilakukan dengan menggunakan software SPSS 16 menghasilkan ralpha sebesar 0,940 , nilai ini didapat dari nilai Cronbach's Alpha. Apabila koefisien reliabilitas mendekati 1, maka kuesioner dikatakan mempunyai reliabilitas yang baik. Selain itu, perbandingan nilai ralpha $(0,940) \geq(0,80)$, hal ini mengindikasikan bahwa atribut - atribut dalam kuesioner adalah reliabel atau handal (reliabilitas good), dimana atribut - atribut tersebut menunjukkan kemantapan atau stabilitas hasil pengamatan bila diukur dengan atribut - atribut tersebut. Berapa kali pun atribut - atribut tersebut ditanyakan kepada responden yang lain dalam interval waktu yang berbeda, hasilnya tidak akan menyimpang terlalu jauh dari rata - rata jawaban responden untuk atribut tersebut.

Gap / kesenjangan yang terdapat pada hasil fuzzy servqual dari gap antara tingkat kepentingan/harapan pelayanan yang didapat oleh nasabah dengan kepuasan / persepsi pelayanan yang didapatkan dari Bank BNI Syariah Kantor Cabang Surabaya. Gap bernilai negatif (-) mengindikasikan bahwa pelayanan jasa yang dipersepsikan tidak sesuai dengan yang diharapkan. Jika gap mendekati nol maka semakin kecil kesenjangan yang terjadi dan jika kinerja yang dilakukan pihak bank sesuai dengan kriteria yang diharapkan nasabah maka pihak bank akan mendapatkan citra serta dampak yang positif. Berikut adalah penjelasan dari analisis servqual tiap dimensi berdasarkan urutan dari gap terbesar sampai dengan gap terkecil.

\subsection{Compliance (Pemenuhan)}

Pada dimensi Compliance, atribut yang berada diurutan pertama adalah atribut menerapkan ketentuan pembagian keuntungan investasi dengan gap negatif terkecil yaitu sebesar -0,350. Nilai ini didapatkan dari skor kepentingan yang lebih tinggi $(3,820)$ daripada nilai kepuasannya $(3,470)$ dimana menandakan bahwa pihak bank masih belum maksimal dalam memenuhi kepuasan nasabah. Maka pihak bank harus melakukan perbaikan pelayan kualitas pada atribut ini seperti misalnya dalam penerapan ketentuan keuntungan investasi (bagi hasil) mempertimbangkan faktor - faktor yang mempengaruhi bagi hasil (seperti : Investment Rate, total dana investasi, jenis dana, nisbah, metode perhitungan bagi hasil dan kebijakan akuntansi), metode perhitungan bagi hasil (seperti : bagi hasil dengan menggunakan revenue sharing atau bagi hasil dengan menggunakan profit / loss sharing), serta mempertimbangkan tahap perhitungan bagi hasil dana pihak ketiga , agar dapat memenuhi kepuasan pelanggannya sehingga para investor tertarik untuk berinvestasi.

Namun sebaliknya, pada atribut menerapkan ketentuan bebas bunga pinjaman memiliki nilai gap negatif terbesar yaitu -0,074. Dengan ditunjukkannya selisih nilai kepuasan dan kepentingan yang tidak terlalu mencolok yaitu masing - masing bernilai 3,571 dan 3,645. Hal ini berarti pihak bank sudah mengupayakan semaksimal mungkin untuk memenuhi kepuasan nasabah dengan diterapkannya ketentuan bebas bunga pinjaman, mengingat prinsip yang digunakan adalah prinsip syariah yang tidak mengenal sistem bunga.

Pada dimensi Compliance atau dimensi pemenuhan memiliki gap mean yang relatif besar, yaitu sebesar -0,225. Hal ini mengindikasikan bahwa secara keselurahan pihak bank masih belum maksimal guna 
meningkatkan kepuasan nasabahnya pada dimensi Compliance.

\subsection{Assurance (Jaminan)}

Atribut jaminan keamanan bagi nasabah memiliki gap positif terbesar yaitu 0,499. Ini berarti pihak bank telah memenuhi kepuasan pelanggan dengan memberikan jaminan keamanan bagi nasabah yang ditunjukkan dengan nilai sebesar 3,944 dan untuk kepentingan sebesar 3,446 sehingga para nasabah merasa mendapatkan jaminan keamanan dalam bertransaksi, dan pihak bank dalam hal ini perlu mempertahankan atribut ini agar nasabah tetap loyal karena untuk mendapat kepercayaan dari nasabah tidaklah mudah.

Akan tetapi, pada atribut memberikan layanan secara menyeluruh dan tuntas memiliki nilai gap negatif terkecil yaitu 0,391 , dimana pihak bank masih belum bisa memberikan kepuasan sesuai yang diharapkan oleh nasabah. Sehingga hal ini bisa menjadikan fokus utama pihak bank untuk meningkatkan pelayanannya dalam hal memberikan layanan secara menyeluruh dan tuntas.

Sedangkan gap mean yang dihasilkan pada dimensi Assurance atau dimensi jaminan relatif kecil yaitu $-0,039$, dan merupakan dimensi dengan gap terbaik diantara kelima dimensi lainnya. Sehingga dapat dikatakan bahwa secara keseluruhan pihak bank telah melakukan usaha yang sangat maksimal untuk memberikan kepuasan kepada nasabah dalam dimensi assurance.

\subsection{Reliability (Kehandalan)}

Pada dimensi reliability, dimana atribut ketepatan waktu pelayanan memiliki nilai kepuasan tertinggi yaitu sebesar 3,637 diantara 2 atribut lainnya, akan tetapi hal itu dirasa masih belum dapat memberikan kepuasan terhadap nasabah karena apa yang dianggap oleh nasabah penting namun belum dipenuhi oleh pihak bank, sehingga gap yang dihasilkan sebesar -0,097 yang merupakan gap negatif terbesar. Maka dari itu pihak bank seharusnya bisa lebih disiplin untuk mengatur ketepatan waktu pelayanannya.

Sedangkan gap mean yang dihasilkan pada dimensi ini memiliki nilai yang cukup besar yaitu $-0,310$. Berarti secara keselurahan pihak bank masih harus meningkatkan pelayanan jasanya untuk memenuhi kepuasan pelanggannya.

\subsection{Tangibles (Bukti Fisik)}

Pada dimensi Tangibles memiliki jumlah atribut terbanyak daripada kelima atribut yang lain. Atribut persyaratan menjadi nasabah tidak berbelit - belit memiliki gap positif terbesar yaitu 0,444 , hal ini membuktikan bahwa adanya kemungkinan nasabah memilih untuk bertransaksi di Bank BNI Syariah karena tidak berbelit - belitnya persyaratan untuk menjadi nasabah di bank tersebut, sehingga memudahkan masyarakat awam untuk menjadi nasabah dan masyarakat selalu menginginkan segala sesuatu yang mudah dan praktis. Nilai kepuasan yang diberikan para nasabah memiliki perbedaan yang cukup signifikan yaitu sebesar 3,731.

Sedangkan para nasabah masih belum mendapatkan kepuasan pada atribut kecukupan pegawai yang menunjang pelaksanaan tugas, hal ini ditunjukkannya dengan gap sebesar -0,446. Akan tetapi, dalam hal ini pihak bank harus memikirkan secara bijaksana apabila nasabah memang merasa bahwa pegawai yang tersedia masih belum cukup, karena untuk penambahan pegawai, pihak bank harus menyesuaikan dengan kebutuhan perusahaan sendiri terutama dari segi modal kerja yang bersifat jangka pendek maupun jangka panjang. Alih - alih ingin menambah pegawai demi meningkatkan kepuasan pelanggan, namun ternyata malah menjadi pemborosan bagi pihak bank.

Namun, jika dilihat pada nilai gap mean yang dihasilkan, pada dimensi ini memiliki nilai terbesar kedua yaitu $-0,055$. Sehingga secara keseluruhan pada dimensi ini pihak bank masih sudah berusaha semaksimal mungkin untuk memberikan pelayanan yang terbaik untuk nasabahnya. 


\subsection{Emphaty (Kemudahan)}

Atribut terjalin komunikasi yang baik antara karyawan dan nasabah memiliki gap negatif terkecil yaitu -0,303, padahal menurut para nasabah atribut ini yang memiliki nilai kepentingan terbesar diantara tujuh atribut lainnya yaitu sebesar 4,024. Maka dari itu, pihak bank seharusnya bisa lebih meningkatkan kualitas layanan pada atribut ini, sehingga nasabah yang melakukan transaksi bisa lebih nyaman karena pegawai yang komunikatif dan menciptakan hubungan interpersonal yang kondusif.

Sebaliknya, nasabah sudah merasa mendapatkan kepuasan dari pihak bank karena mampu mendengarkan aspirasi dan keluhan nasabah. Atribut ini ditunjukkannya dengan nilai kepuasaan sebesar 3,776, nilai kepentingan sebesar 3,528.

Namun, pada dimensi ini secara kesuluruhan pihak bank masih harus mengupayakan dengan meningkatkan kualitas pelayanannya dengan menghasilkan gap mean sebesar -0,141.

\subsection{Responsiveness (Ketanggapan)}

Pada dimensi ini hanya terdapat 2 atribut, akan tetapi kedua atribut tersebut masih belum bisa memenuhi kepuasan para nasabah, hal ini ditunjukkannya dengan masing-masing gap -0,545 dan -0,270 untuk atribut cepat tanggap terhadap keluhan nasabah dan pegawai memberi informasi yang jelas dan mudah dimengerti. Dalam kedua hal ini, pihak bank bisa melakukan training guna mengetahui bagaimana melakukan kontak interpersonal yang baik dengan nasabah kepada seluruh pegawai dan semaksimal mungkin mengupayakan untuk meningkatkan pelayanan kualitas jasanya karena jika kedua atribut tersebut diabaikan, bukan tidak mungkin lagi nasabah yang tadinya loyal menjadi berpaling. Selain itu juga, pada dimensi ini memiliki nilai gap mean sebesar $-0,408$.

\subsection{Diagram Kartesius}

Hasil perhitungan servqual antara tingkat kepentingan dengan tingkat kepuasan kemudian di petakan dalam diagram kartesius yang bertujuan untuk mengetahui posisi masing - masing atribut berada pada kuadran berapa. Pengukuran tingkat kesesuaian dilakukan untuk mencari prioritas perbaikan layanan.

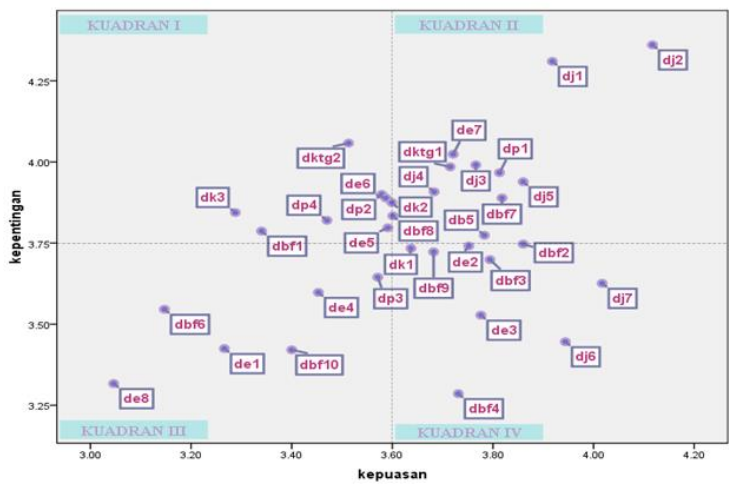

Kuadran I merupakan daerah prioritas utama untuk diperbaiki karena memuat atribut-atribut yang dianggap penting oleh nasabah akan tetapi pada kenyataannya atribut - atribut tersebut bernilai relatif rendah dan belum sesuai seperti yang diharapkan oleh nasabah.

Kuadran II merupakan wilayah yang memuat atribut - atribut yang dianggap penting oleh nasabah dan atribut tersebut dianggap oleh nasabah telah sesuai dengan yang diharapkan sehingga pihak bank harus mempertahankan kualitas pelayanannya, karena harapan tinggi dan persepsi juga tinggi. Pada Kuadran II ini memiliki jumlah atribut terbanyak diantara 3 kuadran lainnya yaitu sebanyak 10 atribut.

Pada Kuadran III memuat 6 atribut, hal ini berarti bahwa keenam atribut tersebut dianggap kurang penting oleh nasabah dan pada kenyataannya biasa saja dan tidak terlalu istimewa. Atau dengan kata lain, wilayah Kuadran III bisa disebut juga sebagai daerah prioritas rendah karena pada daerah ini menunjukkan harapan rendah dan persepsi rendah. Namun, pihak bank harus bisa memberikan sesuatu yang lebih baik agar dapat meningkatkan kualitas pelayanannya. Walaupun pada kuadran ini merupakan daerah prioritas rendah, bukan 
berarti harus diabaikan, karena di masa yang akan datang atribut - atribut yang terdapat pada kuadran ini bisa menjadi tuntutan bagi pihak bank dalam meningkatkan kinerja kualitas pelayanannya.

Kuadran IV dikategorikan sebagai daerah berlebihan karena merupakan wilayah yang memuat atribut-atribut yang dianggap kurang penting oleh nasabah tetapi pada kenyataannya oleh nasabah dirasakan dengan baik. Pada kuadran IV memiliki tingkat harapan rendah namun persepsi tinggi, sehingga hal ini bukan menjadi prioritas yang dibenahi.

\subsection{Atribut Usulan Perbaikan}

Bagian ini membahas atribut yang memerlukan perbaikan untuk meningkatkan kualitas pelayanan. Atribut - atribut tersebut merupakan atribut yang dihasilkan pada diagram kartesius kuadran I dengan nilai gap masing-masing yang dihasilkan pada setiap atribut dan didapatkan nilai gap mean sebesar -0,360, sehingga dapat disimpulkan bahwa layanan yang diberikan tidak berkualitas dan tidak memuaskan karena tingkat harapan lebih besar daripada tingkat persepsi.

Dari dimensi Compliance:

- Menerapkan ketentuan layanan dan produk islami (gap -0,321). Usulan perbaikan adalah menyediakan layanan syar'i sesuai dengan ketentuan islam yang tidak menerapkan sistem bunga.

- Menerapkan ketentuan pembagian keuntungan investasi (gap -0,350). Usulan perbaikan adalah menentukan bagi hasil nasabah dengan pihak bank sesuai dengan akad yang disetujui bersama.

Dari dimensi Reliability:

- Setiap nasabah mendapat layanan yang sama dan adil (gap -0,276). Usulan perbaikan adalah menekankan bahwa semua nasabah adalah sama pentingnya dan tidak ada prioritas.

- Lamanya layanan sesuai dengan waktu yang telah dijanjikan (gap -0,556).
Usulan perbaikan adalah melayani nasabah sesuai dengan antrian.

\section{Dari dimensi Tangibles}

- Kecukupan pegawai yang menunjang pelaksanaan tugas (gap -0,446). Usulan perbaikan adalah menyesuaikan kebutuhan pegawai dengan kebutuhan perusahaan dan modal kerja dalam jangka pendek maupun jangka panjang

- Adanya sarana penunjang kebersihan (gap -0,233). Usulan perbaikan adalah menyediakan peralatan dan perlengkapan kebersihan (misal tempat sampah) yang memadai.

\section{Dari dimensi Emphaty}

- Pihak bank memahami kebutuhan dan keperluan khusus kepada nasabah (gap 0,207). Usulan perbaikan adalah menugaskan satpam/frontliner untuk memberikan arahan sesuai dengan keperluan nasabah.

- Pihak bank memerlakukan nasabah secara penuh perhatian (gap -0,302). Usulan perbaikan adalah memberikan pelayanan sesuai yang diharapkan oleh nasabah.

\section{Dari dimensi Responsiveness}

- Cepat tanggap terhadap keluhan nasabah (gap -0,545). Usulan perbaikan adalah menindaklanjuti dan memberikan pemahaman atas keluhan nasabah.

\section{KESIMPULAN DAN SARAN}

\subsection{Kesimpulan}

Kualitas pelayanan yang selama ini diberikan oleh pihak bank masih belum sesuai dengan harapan nasabahnya dan tidak memenuhi standar. Atribut - atribut yang harus diperhatikan adalah sebagai berikut:

- Menerapkan ketentuan layanan dan produk islami.

- Menerapkan ketentuan pembagian keuntungan investasi.

- Setiap nasabah mendapat layanan yang sama dan adil. 
- Lamanya layanan sesuai dengan waktu yang telah dijanjikan.

- Kecukupan pegawai yang menunjang pelaksanaan tugas.

- Adanya sarana penunjang kebersihan.

- Pihak bank memahami kebutuhan dan keperluan khusus kepada nasabah.

- Pihak bank memerlakukan nasabah secara penuh perhatian.

- Cepat tanggap terhadap keluhan nasabah

\subsection{Saran}

Pihak bank harus bisa meminimalisir antrian akibat lamanya waktu pelayanan terhadap nasabah dengan memberikan estimasi waktu proses pelayanan yang akan diberikan disesuaikan dengan keperluan nasabah. Untuk lebih memudahkan nasabah terhadap nomor antrian, maka pihak bank perlu meng-upgrade sistem nomor antrian dengan antrian digital dan disediakan pula display urutan nomor antrian. Pihak bank harus melakukan penilaian kualitas pelayanan secara berkala sehingga mengetahui bagaimanakah kualitas pelayanan yang diberikan.

Peneliti harus mengetahui standar nilai kualitas yang dimiliki oleh pihak bank sehingga nilai kualitas hasil perhitungan bisa dikomparasikan dengan nilai kualitas pihak bank. Mengetahui metode yang selama ini digunakan oleh pihak bank untuk meningkatkan kualitas pelayanannya, sehingga dari metode tersebut bisa dikembangkan atau sebagai acuan untuk penelitian selanjutnya. Peneliti dapat menggunakan metode yang bisa di integrasikan antara fuzzy servqual dengan metode Quality Function Deployment (QFD), Potential Gain Customer Value (PGCV) indeks, Importance Performance Analysis (IPA) dan Lean Six Sigma.

\section{DAFTAR PUSTAKA}

Bhuono, A. N, Strategi Jitu Memilih Metode Statistik Penelitian dengan SPSS. Andi, Yogyakarta, 2005.

Kusumadewi, S, Artificial Intelligence Teknik dan Aplikasinya. Yogyakarta, Graha Ilmu, 2003.

Nikensari, S. I., Perbankan Syariah: Prinsip, Sejarah \& Aplikasinya. PT. Pustaka Rizki Putra, Semarang, 2012.

Puji Astuti, S., Wiwik W \& Datien Eriska U., Meningkatkan Kualitas Pelayanan di Bank Syariah (Penelitian dengan Fuzzy Servqual dan Dimensi Carter. Jurnal Manajemen Bisnis, Vol 2 No 1. April - Juli 2009 (47-58).

Rahmayanty, N, Manajemen Pelayanan Prima. Graha Ilmu. Yogyakarta, 2010.

Sugiyono, Statistika Untuk Penelitian. CV Alfabeta. Bandung, 2007.

Sujarweni, V. W., SPSS Untuk Penelitian. Pustaka Baru Press. Yogyakarta, 2014.

Tjiptono, F., Service Quality \& Satisfaction. Andi, Yogyakarta, 2005. 